\title{
PENDEKATAN ILMIAH (SCIENTIFIC APPROACH) DALAM PEMBELAJARAN PENDIDIKAN AGAMA ISLAM DAN BUDI PEKERTI KURIKULUM 2013: Studi Analisis Berdasarkan Paradigma Positivistik
}

\author{
Nur Kholifah \\ STAIN Kediri \\ Email: nkholifah301@gmail.com
}

\begin{abstract}
This study reviews the scientific approach of Pendidikan Agama Islam and Budi Pekerti Kurikulum 2013, based on scientific paradigm of positivistic, proposed by Auguste Comte. The results of this study reveal that the scientific approach in the curriculum 2013 is done through some steps: to observe, to question, to reason, to associate and to communicate. This scientific approach is relevant to the positivistic paradigm. The theory stems from the emergence of legal positivism of Law of Three Stages by Auguste Comte. It states that historical development of human thought has evolved in three stages, namely theological or fictitious, metaphysical or abstract, and positive or scientific or real. Thus, according to this approach, if scientific approach is applied in Pendidikan Agama Islam and Budi Pekerti Kurikulum 2013 in the aspect of Aqidah, it becomes less relevant. However, the aspect of Jurisprudence, Morality, Al-Quran Hadith, and Islamic Cultural History, the scientific approach is very appropriate to be applied into the learning process.
\end{abstract}

Keywords: PAI, Character Education, Positivistic Paradigm.

\begin{abstract}
Abstrak: Penelitian ini mengkaji tentang pendekatan ilmiah (scientific approach) dalam pembelajaran Pendidikan Agama Islam dan Budi Pekerti Kurikulum 2013 ditinjau berdasarkan paradigma ilmiah positivistik yang digagas oleh Auguste Comte. Hasil Penelitian ini menjelaskan bahwa pendekatan ilmiah (scientific approach) dalam pembelajaran kurikulum 2013 melalui langkah-langkah mengamati, menanya, menalar, mengasosiasikan, dan mengomunikasikan. Pendekatan ilmiah (scientific approach)dalam kurikulum 2013 relevan dengan paradigma positivistik. Dalam kacamata positivistik, pada pembelajaran Pendidikan Agama Islam dan Budi Pekerti kurikulum 2013, maka pendekatan ilmiah (scientific appoach) kurang relevan untuk diterapkan pada materi aspek Aqidah. Sedangkan pada materi pembelajaran aspek Fiqih, Akhlak, Al-Quran Hadits, Sejarah Kebudayaan Islam maka pendekatan ilmiah (scientific appoach) sangat tepat untuk diterapkan pada proses pembelajaran.
\end{abstract}

Kata Kunci: PAI, Pembelajaran Budipekerti, Paradigma Positifistik 


\section{Pendahuluan}

Kurikulum memainkan peran yang sangat penting dalam mewujudkan generasi yang handal, kreatif, inovatif, dan menjadi pribadi yang bertanggung jawab. Ibarat tubuh, kurikulum merupakan jantungnya pendidikan. Oleh karena itu, kurikulum harus selalu disusun dan disempurnakan sesuai dengan perkembangan zaman dan kebutuhan masyarakat. ${ }^{1}$

Kurikulum 2013 menekankan pada dimensi pedagogik modern dalam pembelajaran, yaitu menggunakan pendekatan ilmiah (scientific approach). Pendekatan ilmiah (scientific approach) mengadopsi langkah-langkah saintis dalam membangun pengetahuan, yakni penonjolan pada dimensi pengamatan, penalaran, penemuan, pengabsahan dan penjelasan tentang suatu kebenaran. Dengan demikian, proses pembelajaran harus dilaksanakan dengan dipandu nilai-nilai, prinsip-prinsip, atau kriteria ilmiah.

Bila menyandingkan antara pendekatan ilmiah (scientific approach) dalam kurikulum 2013 dengan karakteristik Pendidikan Agama Islam dan Budi Pekerti tampak ada pertentangan yang tajam. Pendekatan ilmiah (scientific approach) menghendaki pemikiran yang rasional, kritis dan empiris, sedangkan dalam Pendidikan Agama Islam dan Budi Pekerti ada aspek yang terkadang tidak bisa dirasionalkan, dan ada aspek yang terkadang tidak bisa diraba secara empiris, aspek tersebut adalah Aqidah.

Penelitian ini menggunakan pendekatan library research (studi kepustakaan). Data penelitian ini dihimpun melalui pembacaan dan kajian teks (teks reading) dan selanjutnya dianalisis dengan menggunakan metode analisis isi (content analysis). Metode ini dimaksudkan untuk menganalisis pendekatan ilmiah (scientific approach) pada pembelajaran Pendidikan Agama Islam dan Budi Pekerti kurikulum 2013. Pisau analisis yang digunakan dalam penelitian ini adalah dengan menggunakan paradigma ilmiah positivistik yang digagas oleh Auguste Comte.

\section{Kurikulum 2013}

Kurikulum dalam perspektif yuridis formal, menurut Undang-Undang Nomor 20 tahun 2003 tentang Sistem Pendidikan Nasional, sebagaimana dikutip oleh Zainal Arifin, yaitu: "Kurikulum adalah seperangkat rencana dan pengaturan mengenai tujuan, isi dan bahan pelajaran serta cara yang digunakan

\footnotetext{
${ }^{1}$ Nur Ahid, Evaluasi Pelaksanaan Kurikulum 2013 di Sekolah dan Madrasah (Konsep Fakta dan Tantangan), Makalah disampaikan pada acara Seminar Nasional yang diselenggarakan Program Pascasarjana Sekolah Tinggi Agama Islam Negeri (STAIN) Kediri, tanggal 3 Nopember 2015, 2.
} 
sebagai pedoman penyelenggaraan kegiatan pembelajaran untuk mencapai tujuan pendidikan tertentu." 2

Kurikulum 2013 merupakan kurikulum baru yang mulai diterapkan pada tahun pelajaran 2013/2014. Kurikulum ini merupakan pengembangan dari kurikulum yang telah ada sebelumnya, baik Kurikulum Berbasis Kompetensi (KBK) yang telah dirintis pada tahun 2004 maupun Kurikulum Tingkat Satuan Pendidikan (KTSP)pada tahun 2006. ${ }^{3}$ Orientasi Kurikulum 2013 adalah terjadinya peningkatan dan keseimbangan antara kompetensi sikap (attitude), keterampilan (skill) dan pengetahuan (knowledge). ${ }^{4}$

Hasil akhirnya adalah peningkatan dan keseimbangan antara kemampuan untuk menjadi manusia yang baik (soft skill) dan manusia yang memiliki kecakapan dan pengetahuan untuk hidup secara layak (hard skill) dari peserta didik yang meliputi aspek kompetensi sikap, keterampilan dan pengetahuan. ${ }^{5}$ Melalui konsep itu, hardskill dan softskill dimulai dari Standar Kompetensi Lulusan, Standar Isi, Standar Proses dan Standar Penilaian dapat diwujudkan. ${ }^{6}$

\section{Pendekatan Ilmiah (Scientific Approach) dalam Kurikulum 2013}

Pendekatan Ilmiah menurut Kamus Besar Bahasa Indonesia (KBBI) adalah penggunaan teori suatu bidang ilmu untuk mendekati suatu masalah. ${ }^{7}$ Adapun pengertian pendekatan pembelajaran menurut Hosnan, antara lain sebagai berikut:

Perspektif (sudut pandang; pandangan) teori yang dapat digunakan sebagai landasan dalam memilih model, metode dan teknik pembelajaran. Suatu proses atau perbuatan yang digunakan guru untuk menyajikan bahan pelajaran. Sebagai titik tolak atau sudut pandang terhadap proses pembelajaran, yang merujuk pada pandangan tentang terjadinya suatu proses yang sifatnya masih sangat umum, di dalamnya mewadahi, menginspirasi, menguatkan, dan melatari metode pembelajaran dengan cakupan teoritis tertentu. ${ }^{8}$

\footnotetext{
2Zainal Arifin, Konsep dan Model Pengembangan Kurikulum (Bandung: Remaja Rosdakarya, 2012), 6.

${ }^{3}$ M. Fadlillah, Implementasi Kurikulum 2013 (Yogyakarta: Ar-Ruzz Media, 2014), 16.

4Sholeh Hidayat, Pengembangan Kurikulum Baru (Bandung: Remaja Rosdakarya, 2013), 113.

${ }^{5}$ Kementrian Agama Republik Indonesia, Modul Pelatihan Implementasi Kurikulum 2013 SMP Pendidikan Agama Islam dan Budi Pekerti (Jakarta: Direktorat Pendidikan Agama Islam Ditjen Pendidikan Islam Kementrian Agama RI, 2013), 87.

${ }^{6}$ Sunarti dan Selly Rahmawati, Penilaian dalam Kurikulum 2013 (Yogyakarta: Andi, 2014), 1.

7 Pusat Bahasa, Kamus Besar Bahasa Indonesia Online, dalam http://kbbi.web.id/dekat, diakses tanggal 15 Maret 2016.

${ }^{8}$ M. Hosnan, Pendekatan Saintifik dan Kontekstual dalam Pembelajaran Abad 21 (Bogor: Ghalia Indonesia, 2014), 32.
} 
Pendekatan merupakan kerangka filosofis dan teoritis yang menjadi dasar pijak bagi cara yang ditempuh seseorang untuk mencapai tujuan. ${ }^{9}$ Pembelajaran dengan menggunakan pendekatan ilmiah (scientific approach) merupakan pembelajaran yang mengadopsi langkah-langkah saintis dalam membangun pengetahuan melalui metode ilmiah. ${ }^{10}$ Penelitian yang dilakukan dengan metode ilmiah disebut penelitian ilmiah. Suatu penelitian harus memenuhi beberapa karakteristik untuk dapat dikatakan sebagai penelitian ilmiah. Menurut O. Setiawan Djuharie dalam Limas Dodi, umumnya ada lima karakteristik penelitian ilmiah, yaitu:

Sistematik, berarti suatu penelitian harus disusun dan dilaksanakan secara berurutan sesuai pola dan kaidah yang benar, dari yang mudah dan sederhana sampai yang kompleks.

Logis, suatu penelitian dikatakan benar bila dapat diterima akal dan berdasarkan fakta empirik. Pencarian kebenaran harus berlangsung menurut prosedur atau kaidah bekerjanya akal, yaitu logika. Prosedur penalaran yang dipakai bisa prosedur induktif yaitu cara berpikir untuk menarik kesimpulan umum dari berbagai kasus individual (khusus) atau prosedur deduktif yaitu cara berfikir untuk menarik kesimpulan yang bersifat khusus dari pernyataan yang bersifat umum.

Empirik, suatu penelitian biasanya didasarkan pada pengalaman seharihari (fakta aposteriori), yaitu fakta dari kesan indera yang ditemukan atau melalui hasil coba-coba yang kemudian diangkat sebagai hasil penelitian.

Obyektif, artinya suatu penelitian menjauhi aspek-aspek subyektif yaitu tidak mencampurkannya dengan nilai-nilai etis.

Replikatif, artinya suatu penelitian yang pernah dilakukan harus diuji kembali oleh peneliti lain dan harus memberikan hasil yang sama bila dilakukan dengan metode, kriteria, dan kondisi yang sama. Agar bersifat replikatif, penyusunan definisi operasional variabel menjadi langkah penting bagi seorang peneliti. ${ }^{11}$

Pendekatan ilmiah (scientific approach) adalah pendekatan yang bersifat ilmiah, atau memiliki sifat ilmu. Adapun ilmu sendiri definisinya adalah sekumpulan pengetahuan berdasarkan teori-teori yang disepakati dan dapat secara sistematik diuji dengan seperangkat metode yang diakui dalam bidang

\footnotetext{
${ }^{9}$ Moh Roqib, Ilmu Pendidikan Islam (Yogyakarta: LKIS Yogyakarta, 2009), 90.

${ }^{10}$ Kementrian Pendidikan dan Kebudayaan, Pendidikan Berbasis Kompetensi (Jakarta: Direktorat Jenderal Pendidikan Menengah, 2013), 5.

${ }^{11}$ Limas Dodi, Filsafat Ilmu: Sebuah Pengantar dari Berfikir, Agama, Sosial, Politik, Hingga Ekonomi (Azhar Risalah: t.tp, 2014), 220.
} 
tertentu. Dipandang dari sudut filsafat, ilmu terbentuk karena manusia berusaha berfikir lebih jauh mengenai pengetahuan yang dimilikinya. ${ }^{12}$

Proses pembelajaran dengan berbasis pendekatan ilmiah (scientific approach) harus dipandu dengan kaidah-kaidah ilmiah. Pendekatan ini bercirikan penonjolan dimensi pengamatan, penalaran, penemuan, pengabsahan, dan penjelasan tentang suatu kebenaran. Dengan demikian, proses pembelajaran harus dilaksanakan dengan dipandu nilai-nilai, prinsipprinsip, atau kriteria ilmiah. Menurut Permendikbud No. 65 Tahun 2013 tentang Standar Proses, proses pembelajaran disebut ilmiah jika memenuhi kriteria seperti berikut ini:

a. Substansi atau materi pembelajaran berbasis pada fakta atau fenomena yang dapat dijelaskan dengan logika atau penalaran tertentu; bukan sebatas kirakira, khayalan, legenda, atau dongeng semata.

b. Penjelasan guru, respons peserta didik, dan interaksi edukatif guru-peserta didik terbebas dari prasangka yang serta-merta, pemikiran subjektif, atau penalaran yang menyimpang dari alur berpikir logis.

c. Mendorong dan menginspirasi peserta didik berpikir secara kritis, analitis, dan tepat dalam mengidentifikasi, memahami, memecahkan masalah, dan mengaplikasikan substansi atau materi pembelajaran.

d. Mendorong dan menginspirasi peserta didik mampu berpikir hipotetik dalam melihat perbedaan, kesamaan, dan tautan satu dengan yang lain dari substansi atau materi pembelajaran.

e. Mendorong dan menginspirasi peserta didik mampu memahami, menerapkan, dan mengembangkan pola berpikir yang rasional dan objektif dalam merespons substansi atau materi pembelajaran.

f. Berbasis pada konsep, teori, dan fakta empiris yang dapat dipertanggungjawabkan.

g. Tujuan pembelajaran dirumuskan secara sederhana, jelas, dan menarik sistem penyajiannya.

h. Proses pembelajaran harus terhindar dari sifat-sifat atau nilai-nilai nonilmiah yang meliputi intuisi, ${ }^{13}$ penggunaan akal sehat yang keliru, ${ }^{14}$ prasangka, ${ }^{15}$ penemuan melalui coba-coba, ${ }^{16}$ dan asal berpikir kritis. ${ }^{17}$

\footnotetext{
${ }^{12}$ Noeng Muhadjir, Metodologi Penelitian Kualitatif Pendekatan Positivistik, Rasionalistik, Phenomenologik, dan Realisme Metaphisik Telaah Studi Teks dan Penelitian Agama (Yogyakarta: Bayu Indra Grafika, 1998), 12.

${ }^{13}$ Intuisi sering dimaknai sebagai kecakapan praktis yang kemunculannya bersifat irasional dan individual. Intuisi juga bermakna kemampuan tingkat tinggi yang dimiliki oleh seseorang atas dasar pengalaman dan kecakapannya. Istilah ini sering juga dipahami sebagai penilaian terhadap sikap, pengetahuan, dan keterampilan secara cepat dan berjalan dengan sendirinya. Kemampuan intuitif itu biasanya didapat secara cepat tanpa melalui proses panjang dan tanpa disadari. Namun demikian,
} 
Untuk dapat disebut ilmiah, metode pencarian (method of inquiry) harus berbasis pada bukti-bukti dari objek yang dapat diobservasi, empiris, dan terukur dengan prinsip-prinsip penalaran yang spesifik. Metode ilmiah umumnya memuat rangkaian kegiatan koleksi data atau fakta melalui observasi dan eksperimen, kemudian memformulasi dan menguji hipotesis. Metode ilmiah merujuk pada: (1) adanya fakta, (2) sifat bebas prasangka, (3) sifat objektif, dan (4) adanya analisa. ${ }^{18}$

Selanjutnya secara sederhana pendekatan ilmiah (scientific approach) merupakan suatu cara atau mekanisme untuk mendapatkan pengetahuan dengan prosedur yang didasarkan pada suatu metode ilmiah. Ada juga yang mengartikan pendekatan ilmiah sebagai mekanisme untuk memperoleh pengetahuan yang didasarkan pada struktur logis. ${ }^{19}$ Bernard dalam Keyes sebagaimana dikutip oleh Ahmad Dahlan menyatakan bahwa:

"A scientific method based on three assumptions: (a) that reality is 'out there' to be discovered; (b) that direct observation is the way to discover it; and (c) that material explanations for observable

intuisi sama sekali menafikan dimensi alur pikir yang sistemik. Lihat, Kementrian Pendidikan, Modul Pelatihan., 134.

${ }^{14}$ Guru dan peserta didik harus menggunakan akal sehat selama proses pembelajaran, karena memang hal itu dapat menunjukkan ranah sikap, keterampilan, dan pengetahuan yang benar. Namun demikian, jika guru dan peserta didik hanya semata-mata menggunakan akal sehat dapat pula menyesatkan mereka dalam proses dan pencapaian tujuan pembelajaran. Ibid., 134.

15 Sikap, keterampilan, dan pengetahuan yang diperoleh semata-mata atas dasar akal sehat (comon sense) umumnya sangat kuat dipandu kepentingan seseorang (guru, peserta didik, dan sejenisnya) yang menjadi pelakunya. Ketika akal sehat terlalu kuat didomplengi kepentingan pelakunya, sering kali mereka menjeneralisasi hal-hal khusus menjadi terlalu luas. Hal inilah yang menyebabkan penggunaan akal sehat berubah menjadi prasangka atau pemikiran skeptis. Berpikir skeptis atau prasangka itu memang penting, jika diolah secara baik. Sebaliknya akan berubah menjadi prasangka buruk atau sikap tidak percaya, jika diwarnai oleh kepentingan subjektif guru dan peserta didik. Ibid.

16 Tindakan atau aksi coba-coba sering kali melahirkan wujud atau temuan yang bermakna. Namun demikian, keterampilan dan pengetahuan yang ditemukan dengan cara coba-coba selalu bersifat tidak terkontrol, tidak memiliki kepastian, dan tidak bersistematika baku. Tentu saja, tindakan coba-coba itu ada manfaatnya bahkan mampu mendorong kreatifitas. Karena itu, kalau memang tindakan cobacoba ini akan dilakukan, harus diserta dengan pencatatan atas setiap tindakan, sampai dengan menemukan kepastian jawaban. Misalnya, seorang peserta didik mencoba meraba-raba tomboltombol sebuah komputer laptop, tiba-tiba dia kaget komputer laptop itu menyala. Peserta didik pun melihat lambang tombol yang menyebabkan komputer laptop itu menyala dan mengulangi lagi tindakannya, hingga dia sampai pada kepastian jawaban atas tombol dengan lambang seperti apa yang bisa memastikan bahwa komputer laptop itu bisa menyala. Ibid.

${ }^{17}$ Kemampuan berpikir kritis itu ada pada semua orang, khususnya mereka yang normal hingga jenius. Secara akademik diyakini bahwa pemikiran kritis itu umumnya dimiliki oleh orang yang berpendidikan tinggi. Orang seperti ini biasanya pemikirannya dipercaya benar oleh banyak orang. Tentu saja hasil pemikirannya itu tidak semuanya benar, karena bukan berdasarkan hasil eksperimen yang valid dan reliabel, karena pendapatnya itu hanya didasari atas pikiran yang logis semata. Ibid.

${ }^{18}$ Kementrian Pendidikan dan Kebudayaan, Pendidikan Berbasis Kompetensi (Jakarta: Direktorat Jenderal Pendidikan Menengah, 2013), 5.

19 Rangga Sa'adillah Sandhy Atma Putra, Pendekatan Saintifik dalam Perspektif Pendidikan Islam (Tesis: Digilib UIN Sunan Ampel Surabaya, 2014), 17. 
phenomena are always sufficient, and that metaphysical explanations are never needed". 20

Artinya, metode ilmiah berdasarkan pada 3 asumsi, (a) kenyataan "di luar sana" untuk diketahui, (b) observasi langsung adalah cara mengetahui itu, (c) penjelasan tentang hal-hal pada kejadian yang dapat diamati selalu mencukupi dan penjelasan metafisik tidak pernah dibutuhkan. Jadi pada dasarnya metode ilmiah membuat siswa melakukan berbagai pengalaman belajar melalui observasi dan menjelaskan hasil pengamatannya.

\section{Langkah-langkah pembelajaran dengan Pendekatan Ilmiah (Scientific Approach) dalam Kurikulum 2013}

Pendekatan ilmiah (scientific approach) dalam pelaksanaan pembelajaran kurikulum 2013 diwujudkan dengan dalam bentuk kegiatan mengamati, menanya, menalar/mengeksplorasi, mengasosiasi, dan mengomunikasikan. Kegiatan tersebut diharapkan dapat diterapkan pada semua mata pelajaran. ${ }^{21}$ Langkah-langkah pendekatan ilmiah (scientific appoach) dalam pembelajaran kurikulum 2013 disajikan berikut ini:

a. Mengamati; Kegiatan mengamati dibutuhkan untuk dapat memahami proses terjadinya penemuan data. Mengutip dari Patton, Andayani menyatakan "Tujuan pengamatan adalah mendeskripsikan setting yang dipelajari, aktivitas-aktivitas yang berlangsung, orang-orang yang terlibat dalam aktivitas, dan makna kejadian dilihat dari perspektif mereka yang terlihat dalam kejadian yang diamati tersebut". ${ }^{22}$ Adapun kegiatan mengamati ini adalah dengan membaca, mendengar, menyimak atau melihat (dengan atau tanpa alat).

b. Menanya; Kegiatan belajar pada tahap ini adalah peserta didik mengajukan pertanyaan tentang informasi yang tidak dipahami dari apa yang diamati atau pertanyaan untuk mendapatkan informasi tambahan tentang apa yang diamati (dimulai dari pertanyaan faktual sampai ke pertanyaan yang hipotetik). ${ }^{23}$

\footnotetext{
${ }^{20}$ Ahmad Dahlan, Hakikat Scientific Approach atau Pendekatan Saintifics, dalam http://www.eurekapendidikan.com/2015/09/hakikat-scientific-approachatau.html, diakses tanggal 14 Maret 2016.

${ }^{21}$ Kementrian Pendidikan dan Kebudayaan, Pendidikan Berbasis Kompetensi (Jakarta: Direktorat Jenderal Pendidikan Menengah, 2013), 5.

22 Andayani, Problematika dan Aksioma: dalam Metodologi Pembelajaran Babasa Indonesia (Yogyakarta: Deepublish, 2015), 386.

23 Kementrian Pendidikan dan Kebudayaan, Peraturan Menteri Pendidikan dan Kebudayaan Republik Indonesia Nomor 81 A Tabun 2013 tentang Implementasi Kurikulum (Jakarta: 2013), 35.
} 
c. Menalar; Penalaran adalah proses berfikir yang logis dan sistematis atas fakta-kata empiris yang dapat diobservasi untuk memperoleh simpulan berupa pengetahuan. ${ }^{24}$ Pada langkah ini, dilakukan dengan cara membaca sumber lain (selain buku teks), mengamati objek atau kejadian, juga wawancara dengan sumber yang berkaitan. Jujun S. Suriasumantri dalam bukunya Filsafat Ilmu Sebuah Pengantar Populer, menyebutkan bahwa ciriciri penalaran adalah sebagai berikut:

Ciri yang pertama ialah adanya suatu pola berpikir yang secara luas dapat disebut logika. Dalam hal ini maka dapat kita katakan bahwa tiap bentuk penalaran mempunyai logikanya tersendiri. Atau dapat juga disimpulkan bahwa kegiatan penalaran merupakan suatu proses berpikir logis, di mana berpikir logis di sini harus diartikan sebagai kegiatan berpikir menurut suatu pola tertentu, atau dengan perkataan lain, menurut logika tertentu. Hal ini patut kita sadari bahwa berpikir logis itu mempunyai konotasi yang bersifat jamak (plural) dan bukan tunggal (singular). Suatu kegiatan berpikir bisa disebut logis ditinjau dari suatu logika tertentu, dan mungkin tidak logis ditinjau dari sudut logika yang lain. Hal ini sering menimbulkan gejala apa yang dapat kita sebut sebagai kekacauan penalaran yang disebabkan oleh tidak konsistennya kita dalam mempergunakan pola pikir tertentu. Ciri yang kedua dari penalaran adalah sifat analitik dari proses berpikirnya. Penalaran merupakan suatu kegiatan berpikir yang menyandarkan diri kepada suatu analisis dan kerangka berpikir yang dipergunakan untuk analisis tersebut adalah logika penalaran yang bersangkutan. Artinya penalaran ilmiah merupakan suatu kegiatan analisis yang mempergunakan logika ilmiah, dan demikian juga penalaran lainnya yang mempergunakan logikanya tersendiri pula. Sifat analitik ini, kalau kita kaji lebih jauh, merupakan konsekuensi dari adanya suatu pola berpikir tersebut maka tidak akan ada kegiatan analisis, sebab analisis pada hakikatnya merupakan suatu kegiatan berpikir berdasarkan langkah-langkah tertentu. ${ }^{25}$

Berdasarkan kriteria penalaran tersebut di atas, maka dapat dikatakan bahwa tidak semua kegiatan berpikir mendasarkan diri pada penalaran yang bersifat logis dan analitis. Atau dapat disimpulkan bahwa cara berfikir yang tidak termasuk ke dalam penalaran bersifat tidak logis dan tidak analitik.

d. Mencoba; Aplikasi metode eksperimen atau mencoba dimaksudkan untuk mengembangkan berbagai ranah tujuan belajar, yaitu sikap, keterampilan,

\footnotetext{
${ }^{24}$ Kementrian Pendidikan, Modul Pelatihan., 137.

25Jujun S Suriyasumantri, Filsafat Ilmu Sebuab Pengantar Populer (Jakarta: Pustaka Sinar Harapan, 2009), 43.
} 
dan pengetahuan. ${ }^{26}$ Untuk memperoleh hasil belajar yang nyata atau otentik, peserta didik harus mencoba atau melakukan percobaan, terutama untuk materi atau substansi yang sesuai.

e. Mengomunikasikan; Pada tahap ini peserta didik dapat mengomunikasikan hasil pekerjaan yang telah disusun, baik secara bersama-sama bersama kelompok dan atau secara individu dari hasil kesimpulan yang telah dibuat bersama. Kegiatan mengomunikasikan ini dapat diberikan klarifikasi oleh guru agar peserta didik akan mengetahui secara benar apakah jawaban yang telah dikerjakan sudah benar atau ada yang harus diperbaiki. Hal ini dapat diarahkan pada kegiatan konfirmasi sebagaimana pada standar proses. ${ }^{27}$

\section{Paradigma Ilmu Pengetahuan}

Paradigma dapat diartikan sebagai (a) A set of assumtions and (b) beliefs concerning: yaitu asumsi yang dianggap benar (secara given). Untuk dapat sampai pada asumsi itu harus ada perlakuan empirik (melalui pengamatan) yang tidak terbantahkan; accepted assume to be true. Dengan demikian paradigma dapat dikatakan sebagai $A$ mental window, tempat terdapat "frame" yang tidak perlu dibuktikan kebenarannya karena masyarakat pendukung paradigma telah memiliki kepercayaan. ${ }^{28}$

Pengetahuan pada hakikatnya merupakan segenap apa yang kita ketahui tentang suatu obyek tertentu, termasuk ke dalamnya adalah ilmu. ${ }^{29}$ Sebagai salah satu bidang filsafat, masalah pengetahuan dipersoalkan secara khusus di dalam "epistemologi", yang berasal dari bahasa Yunani episteme, berarti pengetahuan dan bagaimana cara mengetahuinya. ${ }^{30}$ Jadi sains berkaitan dengan sebuah sistem mendapatkan pengetahuan dengan menggunakan observasi dan eksperimentasi untuk menggambarkan atau menerangkan fenomena alam. ${ }^{31}$ Science adalah suatu metode analisis dan menemukan penemuannya dengan hati-hati dalam bentuk "jika, maka". ${ }^{32}$

Sedangkan menurut Ahmad Tafsir, bahwa hakikat sains adalah pengetahuan rasional-empiris. Di samping itu, sains itu sendiri berisikan teori yang menerangkan hubungan sebab akibat, tidak memberi penilaian baik atau

\footnotetext{
${ }^{26}$ Kementerian Pendidikan, Modul Pelatihan., 145.

${ }^{27}$ Hosnan, Pendekatan Saintifik., 76.

${ }^{28}$ Agus Salim, Teori dan Paradigma Penelitian Sosial (Pemikiran Norman K.Denzine E Egon Guba dan Penerapannya) (Yogyakarta: Tiara Wacana Yogya, 2001), 34.

${ }^{29}$ Iu Rusliana, Filsafat Ilmu (Bandung: Refika Aditama, 2015), 10.

30 Suparlan Suhartono, Filsafat Ilmu Pengetahuan (Jogjakarta: Ar-Ruzz Media, 2005), 55.

31 Sutoyo, dkk, Religiousitas Sains (Malang: Universitas Brawijaya Press, 2010), 27.

${ }^{32}$ Nasution, Metode Research (Penelitian Ilmiah) (Jakarta: Bumi Aksara, 2012), 3.
} 
buruk, halal atau haram, sopan atau tidak sopan, melainkan hanya memberikan nilai benar atau salah berdasarkan kriteria atau metode ilmiah yang berlaku umum. ${ }^{33}$

\section{Konsep Paradigma Ilmu Pengetahuan Positivistik Auguste Comte Riwayat Hidup Auguste Comte}

Auguste Comte, bernama lengkap Isidore Auguste Marie François Xavier Comte dilahirkan di Montpellier, pada 19 Januari 1798, dan meninggal pada 5 September 1857, di kota Paris, Prancis. ${ }^{34}$ Comte adalah seorang filosof dan sosiolog asal Prancis yang mengembangkan sebuah paham filsafat yaitu positivisme. Ia juga penemu ilmu sosiologi, ilmu tentang sifat, perilaku, dan perkembangan masyarakat; ilmu tentang struktur sosial, proses sosial, dan perubahannya. ${ }^{35}$ Melalui prinsip positivisme, Comte membangun dasar yang digunakan oleh akademisi saat ini yaitu pengaplikasian metode ilmiah dalam ilmu sosial sebagai sarana dalam memperoleh kebenaran. Ia wafat pada tanggal 5 September 1857, dan dimakamkan di Cimetière du Père Lachaise, Paris. ${ }^{36}$

\section{Perkembangan Pemikiran Manusia Menurut Auguste Comte}

Menurut Comte perkembangan pemikiran manusia berlangsung dalam tiga tahap, yang dikenal dengan istilah Hukum Tiga Tahap. Hukum tiga tahap tersebut merupakan unsur pokok dalam filsafat positivisme Auguste Comte, karena dalam hukum inilah tercermin arti, makna, serta sifat seluruh pandangan filsafatnya. Hukum tiga tahap ini dia jadikan dasar dan titik tolak untuk menerangkan ajarannya tentang sejarah, ilmu pengetahuan, masyarakat, dan agama.

Auguste Comte dalam bukunya The Positiv Philosophy mengatakan:

From the study of the development of human intelligence, in all directions, and through all times, the discovery arises of a great fundamental law, to which it is

\footnotetext{
33 Ahmad Tafsir, Filsafat Ilmu: Mengenai Ontologi, Epistemologi dan Aksiologi Pengetahuan (Bandung: Remaja Rosdakarya, 2004), 25.

34 Auguste Comte, The Positive Philosophy of Auguste Comte Volume 1, Terj. Harriet Martineau (Kitchener: Batoche Books, 2000), 8.

${ }^{35}$ Departemen Pendidikan Nasional, Kamus Besar Bahasa Indonesia (Jakarta: Gramedia Pustaka Utama, 2008), 1332.

${ }^{36}$ Diantara karya Comte yaitu "The Course on Positive Philosophy (1830-1842), diterjemahkan oleh Harriet Martineau dengan judul "The Positive Philosophy of Auguste Comte"), "The System of Positive Polity, or Treatise on Sociology, Instituting the Religion of Humanity", (1851-1854), "The Early Writings" (1820-1829), "Elementary Treatise on Analytic Geometry" (1843), "The PhilosophicalTreatise on Popular Astronomy" (1844), "The Discourse on the Positive Spirit"(1844), "The General View of Positivism" (1848), "Catechism of PositiveReligion" (1852), "Appeal to Conservatives" (1855), "Treatise of UniversalEducation", "System of Positive Industry, or Treatise on the Total Action ofHumanity on the Planet", dan "Treatise of First Philosophy". Comte, dalam http://id.wikipedia.org/wiki/August_Comte, diakses pada 4 Maret 2016.
} 
necessarily subject, find which has a solid foundation of proof, both in the acts of our organization and in our historical experience. The law is this:- that each of our leading conceptions, - each branch of our knowledge,-Dasses successively through three different theoretical conditions: the Theological, or fictitious; the Metaphysical, or abstract; and the Scientific, or positive. In other words, the human mind, by its nature, employs in its progress three methods of philosophizing, the character of which is essentially different, and even radically opposed: viz;, the theological method, the metaphysical, and the positive. Hence arise three philosophies, or general systems of conceptions on the aggregate of phenomena, each of which excludes the others. The first is the necessary point of departure of the human understanding; and the third is its fixed and definitive state. The second is merely a state of transition. ${ }^{37}$

Melalui hukum ini ia menyatakan bahwa sejarah umat manusia, baik secara individual maupun secara keseluruhan, telah berkembang menurut tiga tahapan, yaitu tahap teologi atau fiktif, tahap metafisik atau abstrak, dan tahap positif atau ilmiah atau riil. Adapun perkembangan pemikiran manusia menurut Comte adalah sebagai berikut:

a. Tahap/ periode teologi (fiktif)

Menurut Muhammad Muslih, pada tahap teologik, manusia memandang bahwa segala sesuatu didasarkan atas adanya dewa, roh atau Tuhan. ${ }^{38}$ Contoh yang lebih konkretnya, yaitu dewa Thor saat membenturkan godamnyalah yang membuat guntur terlihat atau Dewi Sri adalah Dewi kesuburan yang menetap di tiap sawah. ${ }^{39}$ Auguste Comte dalam karyanya The Positive Philosophy mengatakan: In the theological state, the human mind, seeking the essential nature of beings, the first and final causes (the origin and purpose) of all effects, - in short, Absolute knowledge, supposes all phenomenato be produced by the immediate action of supernatural beings. ${ }^{40}$

Pada literatur lain Zainudin Maliki menyebutkan bahwa menurut KJ. Veeger, dalam tahap teologis masyarakat percaya akan kekuatan supernatural, dan agama di atas segala-galanya. ${ }^{41}$ Menurut Auguste Comte, tahap teologi ini tidak akan muncul begitu saja, akan tetapi akan muncul melalui tahapan tahapan, yaitu fetisyisme, politeisme, dan monoteisme. ${ }^{42}$

\footnotetext{
${ }^{37}$ Auguste Comte, The Positive Philosophy of Auguste Comte Volume 1, terj. Harriet Martineau (Kitchener: Botache Books, 2000), 27.

${ }^{38}$ Mohammad Muslih, Filsafat Ilmu: Kajian atas Asumsi Dasar Paradigma dan Kerangka Teori Ilmu Pengetabuan, (Yogyakarta: Belukar, 2006), 91.

${ }^{39}$ Muhadjir, Filsafat Ilmu., 120.

${ }^{40}$ Auguste Comte, The Positive Phlosophy., 28.

${ }^{41}$ Zainudin Maliki, Sosisologi Pendidikan (Yogyakarta: Gajah Mada University Press, 2008), 63.

${ }^{42}$ Harry Hamersma, Tokoh-tokoh Filsafat Barat Modern., 55.
} 
K.J Veeger dalam bukunya Realitas Sosial, menjelaskan tentang fetisyisme, politeisme, dan monoteisme sebagai berikut:

Fetiyisme/Animisme, yaitu suatu bentuk kehidupan masyarakat yang didasari oleh pemikiran-pemikiran yang mempunyai anggapan, bahwa segala sesuatu yang berada di sekeliling manusia mempunyai suasana kehidupan yang sama seperti manusia sendiri. Politeisme, yaitu suatu bentuk kehidupan masyarakat yang didasari oleh pemikiranpemikiran yang mempunyai anggapan, bahwa daya pengaruh itu tidak lagi berasal dari benda-benda yang ada di sekeliling manusia, akan tetapi dari benda-benda atau makhluk- makhluk yang tidak kelihatan yang berada di sekitarnya. Monoteisme, yaitu suatu bentuk kehidupan masyarakat yang didasari oleh pemikiran-pemikiran yang mempunyai anggapan bahwa pengaruh dan kekuatan penentu itu tidak lagi berasal dari dewa-dewa, akan tetapi dari satu kekuatan mutlak, adikodrati, yaitu Tuhan yang satu. ${ }^{43}$

b. Tahap/ periode metafisik (abstrak)

Tahap metafisik sebenarnya hanya mewujudkan suatu perubahan saja dari zaman teologis, sebab kekuatan-kekuatan yang adikodrati atau dewa-dewa hanya diganti dengan kekuatan-kekuatan yang abstrak. ${ }^{44}$ Dalam hal ini Auguste Comte menjelaskan:

In the metaphysical state, which is only a modification of the first, the mind supposes, instead of supernatural beings, abstract forces, veritable entities (that is, personified abstractions) inherent in all beings, and capable of producing all phenomena. What is called the explanation of phenomena is, in this stage, a mere reference of each to its proper entity. ${ }^{45}$

Menurut Auguste Comte, walaupun dalam tahap metafisik ini jiwa manusia masih menunjukkan hal yang tidak berbeda dengan apa yang dilakukan dalam tahap teologi, namun pada tahap ini manusia sudah mampu melepaskan dirinya dari kekuatan adikodrati, dan beralih pada kekuatan abstraksinya.

c. Tahap/ periode positif (riil).

Adapun tahap positif adalah masyarakat mempercayai pengertian ilmiah dan manusia berkonsentrasi pada kegiatan observasi untuk menemukan keteraturan dunia fisik maupun sosial.46 Auguste Comte menjelaskan:

${ }^{43}$ KJ. Veeger, Realitas Sosial (Jakarta: Gramedia Pustaka Utama, 1993), 21.

${ }^{44}$ Harun Hadiwijono, Sari Sejarah Filsafat Barat 2 (Yogyakarta: Kanisius, 1983), 111.

45 Auguste Comte, The Positive Phlosophy., 28.

${ }^{46}$ Hadiwijono, Sari Sejarah Filsafat Barat., 111. 
In the final, the positive state, the mind has given over the vain search after Absolute notions, the origin and destination of the universe, and the coituses of phenomena, and applies itself to the study of their laws, - that is, their invariable relations of succession and resemblance. Reasoning and observation, duly combined, are the means of this knowledge. What is now understood when we speak of an explanation of facts is simply the establishment of a connection between single phenomena and some general facts, the number of which continually diminishes with the progress of science. ${ }^{47}$

Menurut Comte, ilmu pengetahuan bersifat positif apabila ilmu pengetahuan tersebut memusatkan perhatian pada gejala-gejala yang nyata dan konkret, tanpa ada halangan dari pertimbangan-pertimbangan lainnya. Asumsi-asumsi ilmu pengetahuan positif itu sendiri, antara lain:

1) Ilmu pengetahuan harus bersifat obyektif (bebas nilai dan netral) seorang ilmuwan tidak boleh dipengaruhi oleh emosionalitasnya dalam melakukan observasi terhadap obyek yang sedang diteliti.

2) Ilmu pengetahuan hanya berurusan dengan hal-hal yang berulang kali.

3) Ilmu pengetahuan menyoroti tentang fenomena atau kejadian alam dari mutualisme simbiosis dan antar relasinya dengan fenomena yang lain. ${ }^{48}$

Dalam perkembangan jiwa manusia, pada batas bahwa manusia tidak lagi merasa puas dengan hal-hal yang abstrak, manusia akan merasa lebih dekat dengan hal-hal atau gejala-gejala yang dapat diterangkan melalui pengamatan berlandaskan hukum-hukum umum yang deskriptif. Dengan menjadi matangnya jiwa manusia, maka manusia tidak lagi merasa terbantu oleh pengetahuan abstrak, akan tetapi yang diperlukan sekarang adalah pengetahuan yang nyata, yang dapat dicapai melalui pengamatan, percobaan, perbandingan, dan berlandaskan hukum yang umum. ${ }^{49}$ Comte menyatakan bahwa:

The Theological system arrived at the highest perfection of which it is capable when it substituted the providential action of a single Being for the varied operations of the numerous divinities which had been before imagined. In the same way, in the last stage of the Metaphysical system, men substitute one great entity (Nature) as the cause of all phenomena, instead of the multitude of entities at first supposed. In the same way, again, the ultimate perfection of the Positive so stem would be (if such perfection could be hoped for) to represent all

\footnotetext{
${ }^{47}$ Auguste Comte, The Positive Phlosophy., 28.

48 Suparlan Suhartono, Sejarah Pemikiran Filsafat Modern (Jogjakarta: Ar-Ruzz, 2005), 58.

${ }^{49}$ Amsal Bakhtiar, Filsafat Ilmu (Jakarta: Rajawali Pers, 2014), 154-155.
} 
phenomena as particular aspects of a single general fact;- such as Gravitation, for instance. 50

\section{Paradigma Ilmu Pengetahuan Positivistik}

Positivisme dirintis oleh August Comte (1798-1857), yang dianggap sebagai Bapak Ilmuwan Sosiologi Barat. Positivisme adalah cara pandang dalam memahami dunia berdasarkan sains. Positivisme adalah pandangan yang menganggap bahwa yang dapat diselidiki atau dipahami adalah data-data yang nyata/empirik, atau yang mereka namakan positif. Positivisme menganggap bahwa yang dapat diselidiki atau dipelajari hanyalah "data-data yang nyata/empirik" atau yang mereka namakan positif. 51

Menurut positivisme, pengetahuan manusia hendaknya tidak melampaui fakta objektif, karena peran subjek tidak lebih dari sekedar instrumen untuk menyalin fakta objektif tersebut. Objek dalam positivisme masih dipersempit dengan standar metodologi. Dengan kata lain, 'pengetahuan' dapat dikatakan ilmiah jika menggunakan fakta positif dan yang digali dengan metodologi ilmiah. ${ }^{52}$

Menurut Emile Durkheim, dalam Muslih menyatakan bahwa obyek studi sosiologi adalah fakta sosial (social-fact): “... any way of acting, wheter fixed or not, capable of exerting over the individual an external constraint; or something which in general over the whole of a given society whilst having an existance of its individual manifestation." 53

Fakta sosial yang dimaksud meliputi: bahasa, sistem hukum, sistem politik, pendidikan dan lain-lain. Di bawah naungan payung positivisme, ditetapkan bahwa objek ilmu pengetahuan maupun pernyataan-pernyataan ilmu pengetahuan (scientific proporsition) haruslah memenuhi syarat-syarat sebagai berikut: dapat di/ter amati (observable), dapat di/terulang (repeatable), dapat di/terukur (measurable), dapat di/teruji (testable) dan dapat di/teramalkan (predictable). ${ }^{54}$

\footnotetext{
${ }^{50}$ Auguste Comte, The Positive Philosophy, terj. Harriet Martineau (London: Batoche Books, 2000), Vol. $1,28$.

${ }^{51}$ Mohammad Adib, Filsafat Ilmu: Ontologi, Epistemologi, Aksiologi, dan Logika Ilmu Pengetabuan (Yogyakarta: Pustaka Pelajar, 2011), 122.

${ }^{52}$ Mohammad Muslih, Pendidikan Islam dalam Perspektif Filsafat Ilmu, Hunafa: Jurnal Studia Islamika Vol. 8, No.1, Juni 2011, 62.

${ }^{53}$ Mohammad Muslih, Filsafat Ilmu (Yogyakarta: Belukar, 2004), 92.

${ }^{54} \mathrm{Ibid}$.
} 
Positivisme Comte berkembang memberi corak positivisme dalam paradigma kualitatif berupa kajian teori antropologo-sosiologi-historik. ${ }^{55}$ Ciriciri positivisme menurut Donny Gahral Adian antara lain:

a. Objektif/ bebas nilai: dikotomi yang tegas antara fakta dan nilai mengharuskan subjek peneliti mangambil jarak dari realitas yang dengan bersikap bebas nilai.

b. Fenomenalisme, tesis bahwa realitas terdiri dari impresi-impresi. Ilmu pengetahuan hanya berbicara tentang realitas berupa impresi-impresi tersebut. Substansi metafisis yang diandalkan berada di belakang gejalagejala penampakan ditolak (antimetafisika)

c. Nominalisme, bagi positifisme hanya konsep yang mewakili realitas partikularlah yang nyata. Contoh: logam dipanaskan memuai, konsep logam dalam pernyataan itu mengatasi semua bentuk partikular logam: besi, kuningan, timah, dll.

d. Reduksionisme, realitas reduksi menjadi fakta-fakta yang dapat diamati.

e. Naturalisme, tesis tentang keteraturan peristiwa-peristiwa di alam semesta yang meniadakan yang meniadakan penjelasan supranatural (adikodrati). Alam semesta memiliki strukturnya sendiri dan mengasalkan strukturnya sendiri.

f. Mekanisme, tesis bahwa semua gejala dapat dijelaskan dengan prinsipprinsip yang dapat digunakan untuk menjelaskan mesin-mesin (systemsistem mekanis). Alam semesta diibaratkan sebagai a giant clock work. ${ }^{56}$

Dengan uraian di atas, dapat dijelaskan bahwa dalam perspektif positivisme, ilmu-ilmu menganut tiga prinsip; bersifat empiris-objektif, deduktif-nomologis, instrumental-bebas nilai. Ketiganya tidak hanya berlaku pada ilmu alam, namun juga berlaku bagi ilmu sosial, dan inilah kontribusi terbesar dari Auguste Comte, yang menghantarkannya sebagai bapak sosiologi modern. ${ }^{57}$ Dalam karyanya yang berjudul "A General View of Positivism” (1971), Auguste Comte menjelaskan maksud dari kata "positif', yaitu:

a. Sebagai lawan atau kebalikan sesuatu yang bersifat khayalan, maka pengertian "positif" pertama-tama diartikan sebagai pensifatan akan sesuatu yang nyata.

\footnotetext{
${ }^{55}$ Noeng Muhadjir, Filsafat ilmu (Yogyakarta: Rake Sarasin, 2011), 120.

${ }^{56}$ Donny Gahral Adian, Percik Pemikiran Kontemporer: Sebuah Pengantar Komprehensif (Yogyakarta: Jalasutra, 2005), 28-29.

57 Aceng Rahmat dkk, Filsafat Ilmu Lanjutan (Jakarta: Kencana, 2011), 171-173.
} 
b. Sebagai lawan atau kebalikan sesuatu yang tidak bermanfaat, maka pengertian "positif" diartikan sebagai pensifatan sesuatu yang bermanfaat..

c. Sebagai lawan atau kebalikan sesuatu yang meragukan, maka pengertian "positif" diartikan sebagai pensifatan sesuatu yang sudah pasti.

d. Sebagai lawan atau kebalikan sesuatu yang kabur atau buram, maka pengertian "positif" diartikan sebagai pensifatan sesuatu yang jelas atau tepat.

e. Sebagai lawan atau kebalikan sesuatu yang negatif, maka pengertian "positif" dipergunakan untuk menunjukkan sifat-sifat pandangan filsafatnya yang selalu menuju ke arah penataan atau penertiban. ${ }^{58}$

\section{Relevansi Pendekatan Ilmiah (Scientific Approach) Dalam Kurikulum 2013 Dengan Paradigma Positivistik.}

Relevansi antara paradigma positivistik dengan pendekatan ilmiah (scientific approach) dalam kurikulum 2013 dapat disajikan pada tabel berikut ini:

\begin{tabular}{|c|c|c|c|}
\hline $\begin{array}{l}\text { Paradigm } \\
\text { Theory }\end{array}$ & Kriteria & $\begin{array}{l}\text { Bentuk dari } \\
\text { Teori }\end{array}$ & Macam Narasi \\
\hline $\begin{array}{l}\text { Positivistist/ Post } \\
\text { Positivist }\end{array}$ & $\begin{array}{l}\text { Internal, ekesternal } \\
\text { validity }\end{array}$ & $\begin{array}{l}\text { Logical-deductive, } \\
\text { scientific dan } \\
\text { mendasar }\end{array}$ & Scientific Report \\
\hline Constructivist & $\begin{array}{l}\text { Afrocentric, } \\
\text { Credibility, } \\
\text { Transferability, } \\
\text { Confirmability }\end{array}$ & Substantive formal & $\begin{array}{l}\text { Interpretasi studi } \\
\text { kasus, ethnographic } \\
\text { fiction, essays, } \\
\text { stories, experimental } \\
\text { writing }\end{array}$ \\
\hline Feminist & $\begin{array}{l}\text { Afrocentric, lived } \\
\text { experimence, } \\
\text { dialogue, caring } \\
\text { accountability, race, } \\
\text { class, gender, } \\
\text { reflexivity, praxis, } \\
\text { emotion, concrete } \\
\text { grounding }\end{array}$ & Critical, standpoint & $\begin{array}{l}\text { Esai, dongeng, } \\
\text { dan drama }\end{array}$ \\
\hline Ethnic & $\begin{array}{l}\text { Afrocentric, lived } \\
\text { experience, dialogue, } \\
\text { caring, }\end{array}$ & $\begin{array}{l}\text { Standpoint, critical } \\
\text { dan bistorical }\end{array}$ & $\begin{array}{l}\text { Historical, } \\
\text { economic, dan } \\
\text { sosiocultural }\end{array}$ \\
\hline
\end{tabular}

${ }^{58}$ Auguste Comte, A General View of Positivism, terj. J. H. Budges dari edisi Prancis: Discours sur L'ensemble du Positivisme (Iowa: Brown Reprints, 1971), 12. 


\begin{tabular}{|c|c|c|c|}
\hline & $\begin{array}{l}\text { accountability, race, } \\
\text { class, gender }\end{array}$ & & analysis \\
\hline Marxist & $\begin{array}{l}\text { Emancipatory } \\
\text { theory, falsifiable, } \\
\text { dialogical, race, } \\
\text { class, gender }\end{array}$ & $\begin{array}{l}\text { Critical, Historical } \\
\text { dan ekonomis }\end{array}$ & $\begin{array}{l}\text { Cultural theory as } \\
\text { criticism }\end{array}$ \\
\hline Cultural studies & $\begin{array}{l}\text { Cultural practice, } \\
\text { praxis, sosial texts, } \\
\text { subjectivities }\end{array}$ & Social Critism & \\
\hline
\end{tabular}

Diambil dari Denzin and Lincoln, "Introduction: Entering the field the Field of Qualitative Research" in Handbook of Qualitative Research, 1994, 13.

Tabel 4.3

Paradigma Enterpretatif

Dalam sintaknya, pendekatan ilmiah (scientific approach) dianggap sebagai salah satu metode induksi (khusus menuju umum) yang dilawankan dengan metode deduktif (umum menuju khusus). Pendekatan ilmiah (scientific approach) yang bersifat induktif dipandang lebih cocok dengan dunia penemuan ilmiah (inquiry) dan dengan dunia pendidikan di sekolah. Hal ini karena pendekatan ilmiah (scientific approach) berangkat dari telaah objek-objek konkret, investigasi, memperoleh pengetahuan baru, atau mengoreksi dan memadukan pengetahuan sebelumnya. Sebagai metode ilmiah, pendekatan ilmiah (scientific approach) memuat serangkaian aktivitas pengumpulan data melalui observasi atau eksperimen, mengolah informasi atau data, menganalisis, kemudian memformulasi, dan menyimpulkan hasil. 59

Positivisme terealisasi dalam pendidikan di Indonesia, sebagai bentuk evaluasi operasional pendidikan dan sistemnya bahkan kurikulumnya. Ide konstruktif yang kemudian muncul adalah bagaimana agar siswa dapat produktif bukan sekedar konsumtif, itulah yang kemudian dikenal dengan istilah Kurikulum 2013 yang bercirikan menggunakan pendekatan ilmiah (scientific approach) dalam proses pembelajarannya dan paling tidak berlandaskan positivisme.

\footnotetext{
${ }^{59}$ Marsigit, "Pendekatan Saintifik dan Implementasinya dalam Kurikulum 2013" dalam https://www.academia.edu/18319458/Pendekatan_saintifik_dan_Penerapannya_dalam_Kurikulum _2013, diakses tanggal 15 April 2016.
} 


\section{Analisis Langkah-Langkah Pendekatan Ilmiah (Scientific Approach) Dalam Pembelajaran Pendidikan Agama Islam Dan Budi Pekerti Kurikulum 2013 Ditinjau Berdasarkan Paradigma Positivistik.}

Mata pelajaran Pendidikan Agama Islam dan Budi Pekerti Kurikulum 2013 terdiri dari lima aspek, yakni Al-Qur'an Hadith, Akidah, Akhlak, Fikih dan Sejarah Kebudayaan Islam. ${ }^{60}$ Lima aspek PAI tersebut memiliki karakteristik yang bermacam-macam.Langkah-langkahpembelajaran dengan pendekatan ilmiah (scientific approach) yang masih menjadi permasalahan untuk mata pelajaran Pendidikan Agama Islam dan Budi Pekerti adalah pada langkah mengamati. Dalam langkah mengamati, peserta didik harus disuguhi materi pembelajaran yang berbasis pada fakta (bisa diindera secara empiris) atau fenomena yang dapat dijelaskan dengan logika atau penalaran tertentu. Bukan hanya sebatas kira-kira, khayalan, legenda, atau dongeng semata. Ini menjadi persolan karena pada aspek Aqidah di dalamnya berisi muatan ketauhidan yang sulit untuk bisa menyajikan fakta yang bisa dibuktikan secara empiris.

Sebagai contohnya adalah ketika membahas keyakinan tentang adanya Malaikat Izroil sebagai malaikat yang bertugas mencabut nyawa. Pertanyaan yang kemudian muncul adalah "Bagaimana guru memberikan fakta mengenai malaikat Izrail yang bisa diinderakan atau disajikan secara empiris?”. ${ }^{61}$

Langkah mengamati merupakan kegiatan empiris yang melibatkan peran pancaindra agar pengamat dapat memotret objek benda secara holistik. ${ }^{62}$ Karena objek yang diamati melibatkan peran pancaindra, maka objek tersebut harus berupa objek fisik-materiil. Persoalan inilah yang menjadi perdebatan dalam mapel PAI. Objek kajian dalam PAI bukan hanya berupa objek fisikmateriil, akan tetapi PAI juga mengkaji objek metafisik yakni hal-hal yang berkaitan dengan alam gaib, seperti malaikat, jin, dan setan. ${ }^{63}$ Lebih dari itu, PAI bahkan mengkaji aspek eskatologis, seperti alam kubur, alam akhirat, surga dan neraka. Bidang kajian metafisik-eskatologis tersebut diturunkan menjadi mata pelajaran Aqidah Akhlaq. ${ }^{64}$

Berlainan dengan agama, atau bentuk-bentuk pengetahuan lainnya, maka ilmu hanya membatasi diri hanya kepada kejadian yang bersifat empiris

\footnotetext{
${ }^{60}$ Peraturan Menteri Agama Nomor 2 Tahun 2008 tentang Standar Kompetensi Lulusan dan Standar Isi.

${ }^{61}$ Rangga Sa'adillah, "Telaah Epistemologis Pendekatan Saintifik Mata Pelajaran Pendidikan Agama Islam”, 346.

${ }^{62}$ Lampiran IV Peraturan Menteri Pendidikan dan Kebudayaan Republik Indonesia Nomor 81 A Tahun 2013 tentang Implementasi Kurikulum, 5-7.

${ }^{63}$ Rosidin, Epistemologi Pendidikan Islam (Yogyakarta: Diandra Kreatif, 2013), 29.

${ }^{64}$ Peraturan Menteri Agama Nomor 2 Tahun 2008 tentang Standar Kompetensi Lulusan dan Standar Isi.
} 
ini. Obyek penelaahan ilmu mencakup seluruh aspek kehidupan yang dapat diuji oleh panca indra manusia. Dalam batas-batas tersebut maka ilmu mempelajari obyek-obyek empiris. Ilmu mempelajari berbagai gejala dan peristiwa yang menurut anggapannya mempunyai manfaat bagi kehidupan manusia. Berdasarkan obyek yang ditelaahnya, maka ilmu dapat disebut sebagai suatu pengetahuan empiris, di mana obyek-obyek yang berbeda di luar jangkauan manusia tidak termasuk ke dalam bidang penelaahan keilmuan tersebut. Inilah yang merupakan salah satu ciri ilmu yakni orientasi terhadap dunia empiris. ${ }^{65}$

Mengenai batas-batas penjelajahan ilmu, Jujun S. Suriasumantri menjelaskan bahwa:

Ilmu memulai penjelajahannya pada pengalaman manusia dan berhenti di batas pengalaman manusia. Ilmu tidak mempelajari hal ihwal surga dan neraka, sebab surga dan neraka berada di luar jangkauan pengalaman manusia. Ilmu juga tidak mempelajari sebab musabab kejadian terciptanya manusia, sebab kejadian itu berada di luar jangkauan pengalaman kita. Baik hal-hal yang terjadi sebelum hidup kita, maupun apa-apa yang terjadi sesudah kematian kita, semua itu berada di luar penjelajahan ilmu.

Ilmu hanya membatasi dari hal-hal yang berbeda dalam batas pengalaman manusia karena fungsi ilmu dalam kehidupan manusia yakni sebagai alat pembantu manusia dalam menanggulangi masalahmasalah yang dihadapinya sehari-hari. Ilmu diharapkan dapat membantu manusia untuk memerangi penyakit, membangun jembatan, membuat irigasi, membangkitkan tenaga listrik, mendidik anak, memeratakan pendapatan nasional, dan sebagainya. Persoalan mengenai hari kemudian tidak akan dapat ditanyakan kepada ilmu, melainkan kepada agama, sebab agamalah pengetahuan yang mengkaji masalahmasalah seperti itu. Ilmu membatasi lingkup penjelajahannya pada batas pengalaman manusia juga disebabkan metode yang dipergunakan dalam menyusun yang telah teruji kebenarannya secara empiris. Apabila ilmu memasukkan daerah di luar batas pengalaman empirisnya, maka manusia tidak akan dapat melakukan pembuktian secara metodologis. Hal ini merupakan suatu kontradiksi yang menghilangkan kesahihan metode ilmiah. ${ }^{66}$

Dalam kegiatan mengamati objek yang metafisik-eskatologis tidak diperkenankan mengada-adakan sesuatu yang tidak bisa dijangkau oleh akal dan indra manusia. Maksudnya, perlu disadari bahwa pancaindra yang

${ }^{65}$ Jujun S Suriasumantri, Ilmu dalam Perspektif (Jakarta: Gramedia, 1982), 5.

66Jujun S Suriasumantri, Filsafat Ilmu Sebuah Pengantar Populer (Jakarta: Pustaka Sinar Harapan, 2009), 91. 
diberikan oleh Allah kepada manusia memang hanya mampu mengamati objek yang bersifat fisik-materil. Sementara itu, objek pengamatan yang bersifat metafisik-eskatologis hanya diinformasikan oleh Allah melalui kalâm dan utusan-Nya (al- Qur'ân dan al-Sunnah). Oleh karena itu, objek yang diinformasikan melalui wahyu tersebut harus berangkat dari sikap percaya (iman) terhadap pernyataan-pernyataan dari wahyu tanpa koreksi sama sekali sehingga ia bersifat a priori ${ }^{67}$. Dengan menyandarkan pada sifat a priori tersebut, intuisi sebagai kerangka berpikir pendekatan ilmiah (scientific approach) dalam mapel PAI tidak dapat dinafikan.

\section{Penutup}

Berdasarkan uraian di atas, maka dalam penelitian ini dapat disimpulkan bahwa Pendekatan Ilmiah (scientific approach) dalam pelaksanaan pembelajaran kurikulum 2013 diwujudkan dengan dalam bentuk kegiatan mengamati, menanya, mencoba, mengolah, menyajikan, menyimpulkan dan mencipta. Pendekatan Ilmiah (scientific approach) dalam kurikulum 2013 relevan dengan paradigma positivistik. Positivisme adalah cara pandang dalam memahami dunia dengan berdasarkan sains. Positivisme merupakan pandangan yang menganggap bahwa yang dapat diselidiki atau dipelajari hanyalah "data-data yang nyata/empirik" atau yang mereka namakan positif. Dalam kacamata paradigma positivistik, Pendekatan ilmiah (scientific appoach) kurang relevan jika diterapkan pada materi pembelajaran Pendidikan Agama Islam dan Budi Pekerti Kurikulum 2013 aspek Aqidah. Akan tetapi, pada aspek fiqih, akhlak, al Quran Hadits, sejarah kebudayaan islam maka pendekatan ilmiah (scientific appoach) sangat tepat untuk diterapkan pada proses pembelajaran.

\section{Daftar Pustaka}

Adian, Donny Gahral. Percik Pemikiran Kontemporer: Sebuah Pengantar Komprehensif. Yogyakarta: Jalasutra, 2005.

Adib, Mohammad. Filsafat Ilmu: Ontologi, Epistemologi, Aksiologi, dan Logika Ilmu Pengetahuan. Yogyakarta: Pustaka Pelajar, 2011.

Ahid, Nur. "Evaluasi Pelaksanaan Kurikulum 2013 di Sekolah dan Madrasah (Konsep Fakta dan Tantangan)", Makalah disampaikan pada acara Seminar Nasional yang diselenggarakan Program Pascasarjana Sekolah Tinggi Agama Islam Negeri (STAIN) Kediri, tanggal 3 Nopember 2015.

\footnotetext{
${ }^{67}$ Rosidin, Epistemologi Pendidikan Islam (Yogyakarta: Diandra Kreatif, 2013), 30.
} 
Andayani, Problematika dan Aksioma: dalam Metodologi Pembelajaran Bahasa Indonesia. Yogyakarta: Deepublish, 2015.

Arifin, Zainal. Konsep dan Model Pengembangan Kurikulum. Bandung: Remaja Rosdakarya, 2012.

Bakhtiar, Amsal. Filsafat Ilmu. Jakarta: Rajawali Pers, 2014.

Comte, Auguste, dalam http://id.wikipedia.org/wiki/August_Comte, diakses pada 4 Maret 2016.

Comte, Auguste. A General View of Positivism, terj. J. H. Budges dari edisi Prancis: Discours sur L'ensemble du Positivisme. Iowa: Brown Reprints, 1971.

Comte, Auguste. The Positive Philosophy of Auguste Comte Volume 1, Terj. Harriet Martineau. Kitchener: Batoche Books, 2000.

Dahlan, Ahmad Hakikat Scientific Approach atau Pendekatan Saintifics, dalam http://www.eurekapendidikan.com/2015/09/hakikat-scientificapproachatau.html, diakses tanggal 14 Maret 2016.

Denzin, Norman K. dan Yvonna S. Lincoln. Handbook of Qualitative Research, terj. Dariyanto dkk. Yogyakarta: Pustaka Pelajar, 2009.

Departemen Pendidikan Nasional. Kamus Besar Bahasa Indonesia. Jakarta: Gramedia Pustaka Utama, 2008), 1332.

Dodi, Limas. Filsafat Ilmu: Sebuah Pengantar dari Berfikir, Agama, Sosial, Politik, Hingga Ekonomi. Azhar Risalah: t.tp, 2014.

Fadlillah, M. Implementasi Kurikulum 2013. Yogyakarta: Ar-Ruzz Media, 2014.

Hadiwijono, Harun. Sari Sejarah Filsafat Barat 2. Yogyakarta: Kanisius, 1983.

Hamersma, Harry. Tokoh-tokoh Filsafat Barat Modern. Jakarta: Gramedia Pustaka Utama, 1992.

Hidayat, Sholeh Pengembangan Kurikulum Baru. Bandung: Remaja Rosdakarya, 2013.

Hosnan, M. Pendekatan Saintifik dan Kontekstual dalam Pembelajaran Abad 21. Bogor: Ghalia Indonesia, 2014.

Kementerian Agama Republik Indonesia. Modul Pelatihan Implementasi Kurikulum 2013 SMP Pendidikan Agama Islam dan Budi Pekerti. Jakarta: Direktorat Pendidikan Agama Islam Ditjen Pendidikan Islam Kementerian Agama RI, 2013.

-------. "Lampiran IV Peraturan Menteri Pendidikan dan Kebudayaan Republik Indonesia Nomor 81 A Tahun 2013 tentang Implementasi Kurikulum.”

-------. "Peraturan Menteri Agama Nomor 2 Tahun 2008 tentang Standar Kompetensi Lulusan dan Standar Isi."

- "Peraturan Menteri Pendidikan dan Kebudayaan Republik Indonesia Nomor 81 A Tahun 2013 tentang Implementasi Kurikulum”. Jakarta: 2013.

. Pendidikan Berbasis Kompetensi. Jakarta: Direktorat Jenderal Pendidikan Menengah, 2013. 
Maliki, Zainudin. Sosisologi Pendidikan. Yogyakarta: Gajah Mada University Press, 2008.

Marsigit, "Pendekatan Saintifik dan Implementasinya dalam Kurikulum 2013" dalam

https://www.academia.edu/18319458/Pendekatan_saintifik_dan_Pene rapannya_dalam_Kurikulum_2013, diakses tanggal 15 April 2016.

Muhadjir, Noeng. Filsafat Ilmu. Yogyakarta: Rake Sarasin, 2011.

-------. Metodologi Penelitian Kualitatif Pendekatan Positivistik, Rasionalistik, Phenomenologik, dan Realisme Metaphisik Telaah Studi Teks dan Penelitian Agama. Yogyakarta: Bayu Indra Grafika, 1998.

Muslih, Mohammad. "Pendidikan Islam dalam Perspektif Filsafat Ilmu". Hunafa: Jurnal Studia IslamikaVol. 8, No.1, 2011.

-------. Filsafat Ilmu: Kajian atas Asumsi Dasar Paradigma dan Kerangka Teori Ilmu Pengetahuan. Yogyakarta: Belukar, 2006.

-------. Filsafat Ilmu. Yogyakarta: Belukar, 2008.

Pusat Bahasa. "Kamus Besar Bahasa Indonesia Online". dalam http:/ / kbbi.web.id/dekat, diakses tanggal 15 Maret 2016..

Rahmat, Aceng. Filsafat Ilmu Lanjutan. Jakarta: Kencana, 2011.

Rahmawati, Selly dan Sunarti. Penilaian dalam Kurikulum 2013. Yogyakarta: Andi, 2014.

Roqib, Moh. Ilmu Pendidikan Islam. Yogyakarta: LkiS Yogyakarta, 2009.

Rosidin. Epistemologi Pendidikan Islam. Yogyakarta: Diandra Kreatif, 2013.

Rusliana, Iu. Filsafat Ilmu. Bandung: Refika Aditama, 2015.

Sa'adillah, Rangga dan Kusaeri "Telaah Epistemologis Pendekatan Saintifik Mata Pelajaran Pendidikan Agama Islam". ISLAMICA: Jurnal Studi Keislaman Volume 9 Nomor 2 Maret 2015.

Salim, Agus. Teori dan Paradigma Penelitian Sosial Pemikiran Norman K.Denzin\& Egon Guba dan Penerapannya). Yogyakarta: Tiara Wacana Yogya, 2001.

Suhartono, Suparlan. Filsafat Ilmu Pengetahuan. Jogjakarta: Ar-Ruzz Media, 2005.

Suriasumantri, Jujun S. Ilmu dalam Perspektif. Jakarta: Gramedia, 1982.

-------. Filsafat Ilmu Sebuah Pengantar Populer. Jakarta: Pustaka Sinar Harapan, 2009.

Sutoyo, dkk. Religiousitas Sains. Malang: Universitas Brawijaya Press, 2010.

Tafsir, Ahmad. Filsafat Ilmu (Mengurai Ontologi, Epistemologi dan Aksiologi Pengetahuan). Bandung: Remaja Rosdakarya, 2012.

Veeger, K.J. Realitas Sosial. Jakarta: Gramedia Pustaka Utama, 1993 